\title{
Neural mechanisms of temporomandibular joint and masticatory muscle pain: A possible role for peripheral glutamate receptor mechanisms
}

\author{
David K Lam DDS, Barry J Sessle BDS BSc MDS PhD FRSC, Brian E Cairns PhD RPh, James W Hu PhD
}

DK Lam, BJ Sessle, BE Cairns, JW Hu. Neural mechanisms of temporomandibular joint and masticatory muscle pain: A possible role for peripheral glutamate receptor mechanism. Pain Res Manage 2005;10(3):145-152.

\begin{abstract}
The purpose of the present review is to correlate recent knowledge of the role of peripheral ionotropic glutamate receptors in the temporomandibular joint and muscle pain from animal and human experimental pain models with findings in patients. Chronic pain is common, and many people suffer from chronic pain conditions involving deep craniofacial tissues such as temporomandibular disorders or fibromyalgia. Animal and human studies have indicated that the activation of peripheral ionotropic glutamate receptors in deep craniofacial tissues may contribute to muscle and temporomandibular joint pain and that sex differences in the activation of glutamate receptors may be involved in the female predominance in temporomandibular disorders and fibromyalgia. A peripheral mechanism involving autocrine and/or paracrine regulation of nociceptive neuronal excitability via injury or inflammation-induced release of glutamate into peripheral tissues that may contribute to the development of craniofacial pain is proposed.
\end{abstract}

Key Words: Excitatory amino acid receptor; Neuroplasticity; Nociception; Sensitization; Trigeminal; Vanilloid receptor

\section{Mécanismes neuraux de la douleur affectant l'articulation temporomandibulaire et le muscle masticateur : Rôle possible et mécanismes des récepteurs périphériques du glutamate}

\begin{abstract}
Le but du présent article est d'établir une corrélation entre d'une part, les connaissances récemment acquises sur le rôle des récepteurs inotropes périphériques du glutamate dans l'articulation temporomandibulaire et la douleur musculaire à partir de modèles expérimentaux de douleur chez l'animal et l'être humain, et d'autre part, les observations notées chez les patients. La douleur chronique est fréquente et bien des gens souffrent de maux chroniques impliquant les tissus cranio-faciaux profonds, tels que les troubles temporomandibulaires ou la fibromyalgie. Des études menées chez l'animal et l'être humain ont indiqué que l'activation des récepteurs inotropes périphériques du glutamate dans les tissus cranio-faciaux profonds contribue à la douleur musculaire et à la douleur de l'articulation temporomandibulaire et que des différences liées au sexe quant à l'activation des récepteurs du glutamate pourraient être en cause dans la prédominance des troubles temporomandibulaires et de la fibromyalgie chez la femme. On propose ici un mécanisme périphérique reposant sur la régulation autocrine et/ou paracrine de l'excitabilité nociceptive neuronale par le biais de la libération du glutamate induite par une lésion ou une inflammation dans les tissus périphériques pour expliquer en partie le développement de la douleur cranio-faciale.
\end{abstract}

$\mathrm{C}$ hronic pain is a common affliction and as many as $10 \%$ of the North American population suffer from chronic pain conditions involving deep craniofacial tissues, such as temporomandibular disorders (TMD) or fibromyalgia, at some point in their lives (1-3). In the case of TMD, approximately $70 \%$ of TMD patients are women of reproductive age, and the principal signs and symptoms include neuromuscular dysfunction and pain in the temporomandibular joint (TMJ) and/or the masticatory muscles, joint sounds and limitations in jaw movements. TMD patients frequently have allodynia and hyperalgesia, and pain may also spread and be referred to other craniofacial sites $(1,4-7)$. These findings suggest a role for both peripheral and central sensitization in TMD-associated pain. Another pain condition that is associated with peripheral and central sensitization is fibromyalgia, which is often found in combination with TMD (7-9). The underlying nociceptive mechanisms in muscles and joints in these craniofacial pain conditions are still unclear, in large part due to the limited study of peripheral and central neural mechanisms affecting craniofacial musculoskeletal tissues and, as a consequence, diagnosis and management have a limited scientific rationale.
Despite the many breakthroughs in pain research, our current understanding of the neural mechanisms of musculoskeletal pain still derive mainly from muscle and knee or ankle joint models. Most of these experimental studies have suggested that inflammatory irritants and ligands for G-protein-coupled receptors such as bradykinin, histamine, serotonin and prostaglandins may be responsible for increased primary afferent sensitivity (primary hyperalgesia or peripheral sensitization) and spinal neuron sensitivity (secondary hyperalgesia or central sensitization) under experimental myositic or arthritic joint conditions $(10,11)$. While injury, inflammation or degeneration of the TMJ or muscle are often conceptualized as important in the pathophysiology of chronic craniofacial pain conditions such as TMD, the majority of TMD do not appear to be associated with gross indications of inflammatory changes $(6,12,13)$. Also, more generalized pain conditions such as fibromyalgia do not often show signs of tissue damage or inflammatory changes $(8,9)$. This suggests that different receptor mechanisms may underlie the development of some chronic pain conditions involving deep musculoskeletal tissues and inflammatory pain. 


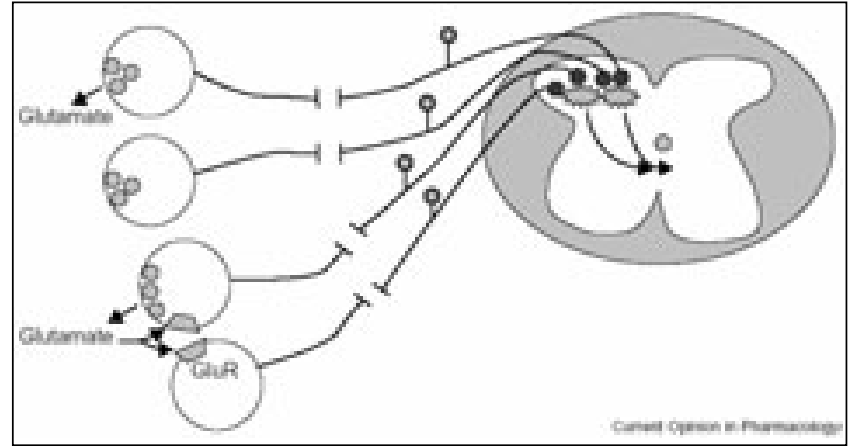

Figure 1) Peripheral glutamate receptor (GluR)-mediated autocrine and/or paracrine regulation of spinal nociceptive transmission. Schematic drawing of cutaneous nociceptive primary afferent fibres. In the normal state, many of the terminals contain glutamate in vesicles that are released on stimulation. Through autocrine and/or paracrine routes, GluRs on a subpopulation of nociceptors can be activated, initiating or enhancing nociceptive transmission to the spinal cord. Reprinted with permission from reference 45

Research in our laboratories has led us to propose an alternative peripheral mechanism involving ionotropic excitatory amino acid (EAA) channel type receptors that may be more relevant to conditions such as TMD and fibromyalgia. We have found that activation of peripheral EAA receptors by injection of the EAA glutamate into the TMJ or craniofacial muscles excites nociceptive afferent fibres and evokes jaw muscle electromyographic (EMG) activity similar to that produced by the injection of inflammatory algesic chemicals (eg, mustard oil), but does not result in any signs of inflammation in these tissues (14-22). In correlated human studies, intramuscular injection of glutamate has been shown to elicit pain in humans (16,23-25). Thus, glutamate may be a better candidate than traditional algesic/inflammatory mediators (eg, bradykinin, serotonin, histamine or prostaglandins) for studying noninflammatory musculoskeletal pain mechanisms such as TMD and fibromyalgia. The purpose of the present review is to correlate recent knowledge of the role of peripheral ionotropic glutamate receptors in TMJ and masticatory muscle pain from studies in animals and human experimental pain models, with clinical findings in craniofacial pain patients.

\section{PERIPHERAL GLUTAMATE RECEPTOR MECHANISMS}

\section{Glutamate}

Glutamate is a well-known and ubiquitous excitatory neurotransmitter in the central nervous system. Recent evidence has suggested that it has an important nociceptive role in peripheral tissues. Glutamate is the endogenous agonist for EAA receptors. There are two broad groups of EAA receptors, namely, the ionotropic EAA receptors, which are mixed cation channels, and metabotropic EAA receptors, which are G-protein-linked. Ionotropic EAA receptor subtypes are named for the agonist that activates them and include the $\mathrm{N}$-methyl-D-aspartate (NMDA) receptors, and the non-NMDA $\alpha$-amino-3-hydroxy5-methyl-5-isoxazolepropionate (AMPA) and kainate receptors. EAA receptors are found on both trigeminal and dorsal root ganglion neurons $(26,27)$ and unmyelinated terminals of cutaneous afferent fibres $(28,29)$. Glutamate itself is present in both trigeminal and dorsal root ganglion neurons (30-36) as well as their central $(36,37)$ and peripheral $(36,38)$ terminals.
Nociceptive stimulation of primary afferent fibres results in the release of EAAs from the central terminals of trigeminal and spinal afferent fibres $(30-35,37,39-42)$. It is not known whether glutamate is also released from the peripheral endings of trigeminal afferent fibres but nociceptive stimulation of spinal afferent fibres has been shown to result in the neurogenic release of glutamate from peripheral terminals of spinal afferent fibres $(43,44)$. Because sensory nerve terminals contain glutamate receptors and release glutamate, it has been suggested that there is a possible role for autocrine and/or paracrine regulation of spinal nociceptor excitability (Figure 1) (45). Similarly, because NMDA and non-NMDA receptors are found on trigeminal ganglion neurons and can be activated by glutamate to depolarize trigeminal ganglion neurons in vitro $(27,46-48)$, this may suggest a similar role for peripheral glutamate receptor modulation of trigeminal nociception.

Peripheral EAA receptor mechanisms may have an important role in inflammatory pain because peripheral glutamate levels are elevated during cutaneous or deep tissue inflammation $(43,49,50)$ and the number of EAA receptors in cutaneous tissues increases during inflammation (51). Furthermore, a number of studies have provided behavioural evidence in support of a role for peripheral glutamate receptors in the transduction of nociceptive information. Subcutaneous or intra-articular glutamate injection decreases mechanical paw withdrawal thresholds in rats through the activation of peripheral NMDA, kainate and AMPA receptors (28,52-54). In rats, the development of thermal and mechanical hyperalgesia observed after intraplantar or intra-articular (knee) application of irritant chemicals can be mimicked by the application of EAA receptor agonists to these sites $(28,52,53,55,56)$. It has also been reported that peripheral application of selective EAA receptor antagonists may attenuate behavioural signs of hyperalgesia induced by irritant chemicals $(53,56-58)$. Moreover, intraplantar injection of NMDA results in a dose-dependent increase in $c$-fos expression (a marker for nociceptive activity) in the ipsilateral dorsal horn, and the co-injection of an NMDA receptor antagonist with formalin suppresses formalin-induced $c$-fos expression (59).

It is thus possible that under certain conditions, such as in the presence of TMD, an increase in peripheral levels of glutamate in craniofacial tissues activates peripheral EAA receptors, a process that can modify the excitability of trigeminal afferent fibres and evoke nociception. Because trauma has long been implicated in the etiology and pathogenesis of certain TMD, it is possible that injury-induced tissue cell damage excites and sensitizes nociceptors through the release of cytosolic glutamate from affected neurons, macrophages (60), released blood serum (61) or Schwann cells (62). Because sensory endings of nociceptors are unencapsulated, they are readily susceptible to cytosolic contents released from damaged cells nearby (63-66). Cytosolic concentrations of $\mathrm{K}^{+}$and ATP are higher than in the extracellular medium and, if released, can depolarize nociceptors through resting $\mathrm{K}^{+}$channels and purinergic receptors, respectively $(66,67)$. The release of high cytosolic concentrations of protons following cell damage can also depolarize nociceptors through proton-gated ion channels such as the vanilloid type 1 (TRPV1) receptor (68-71). This receptor is activated by the inflammatory irritant capsaicin, protons or noxious heat and results in the neurogenic (vesicular) release of EAAs, including glutamate, from peripheral terminals (44). Similar to the nociceptor-depolarizing effects due 
to the cytosolic release of $\mathrm{K}^{+}$, ATP and $\mathrm{H}^{+}$, cytosol also has a high concentration of glutamate that, if released in the extracellular medium, has been shown to activate kainate channels on sensory neurons (72). In particular, cutaneous nociceptors in vitro can be excited and sensitized by exogenous application of glutamate (73). It is also possible that plasma extravasation and/or a neurogenic release secondary to microtrauma, inflammation or TRPV1 receptor activation could play a role in elevating the local glutamate concentration at the site of injury or inflammation.

\section{Animal TMJ and craniofacial muscle models}

Animal studies have suggested that tissue inflammation or injury-related increased levels of peripheral glutamate may be involved in nociceptive mechanisms in deep craniofacial tissues. Glutamate has been shown to excite trigeminal ganglion neurons through the activation of NMDA and non-NMDA receptors (46-48). The authors have recently identified a novel peripheral nociceptive role for glutamate within the TMJ and craniofacial muscles by demonstrating that injection of glutamate into the TMJ or masseter and temporalis muscles evokes both peripheral and central sensitization through the activation of peripheral EAA receptors. In the authors' acute rat model of TMJ injury, glutamate injection into the TMJ evoked a concentration-related reflex increase in jaw muscle EMG activity (15) similar to that evoked by the inflammatory irritants and algogenic compounds in mustard oil (14) and capsaicin (74). This glutamate-evoked reflex response appears to reflect the integration of primary afferent drives with the central sensitization of central neurons involved in the TMJ reflex pathway because it can be abolished by brainstem lesions of the trigeminal subnucleus caudalis $(75,76)$. The reflex response includes the co-contraction of jaw-opening and jaw-closing muscles, which is thought to represent a physiological 'splinting' action to limit movement and prevent further injury (77-79). Moreover, this glutamate-evoked jaw muscle activity can be significantly attenuated by the co-injection of NMDA and nonNMDA receptor antagonists into the TMJ (15). Thus, these results suggest that peripheral ionotropic glutamate receptors are present in deep craniofacial tissues and, when activated, can evoke nociceptive responses similar to those evoked by algogenic compounds. Peripheral metabotropic glutamate receptors also cannot be overlooked, but their relative contribution to peripheral nociceptive responses has not been studied in detail in the trigeminal system. However, they may contribute to craniofacial nociception because they have been shown to modulate both peripheral and central spinal nociceptive transmission (80-83).

Intramuscular (masseter or temporalis) or TMJ injection of glutamate can also preferentially evoke activity in small-diameter, mechanosensitive afferent fibres and sensitize muscle and TMJ afferent fibres through the activation of peripheral EAA receptors $(16-18,21,22,84)$. In particular, peripheral NMDA receptors may play an important role in glutamate-induced effects on nociceptive afferent fibres because NMDA receptor antagonists applied locally into the masseter muscle significantly decrease glutamate-evoked afferent discharges (23). Moreover, the concentration of glutamate injected into the masseter muscle to evoke afferent discharges through peripheral NMDA receptor activation approximates the concentration of glutamate that could be released on afferent excitation from presynaptic vesicles in masseter muscle afferent fibre terminals
$(84,85)$. This glutamate-evoked sensitization of primary afferent fibres may contribute to the primary hyperalgesia or allodynic states characteristic of craniofacial pain conditions such as TMD. Moreover, glutamate injection into the rat TMJ also evokes activity and central sensitization (receptive field expansion, mechanical activation threshold reduction and increases in responses to suprathreshold stimuli and neuronal spontaneous activity) in brainstem nociceptive neurons $(86,87)$ similar to the neuronal changes evoked by the inflammatory irritants and small-fibre excitants capsaicin and mustard oil $(86,88,89)$. Glutamate-evoked receptive field expansion, mechanical activation threshold reduction, increases in responses to suprathreshold stimuli and neuronal spontaneous activity may be centrally operating mechanisms contributing to pain spread and referral, allodynia, hyperalgesia and pain at rest in craniofacial pain conditions such as TMD.

In addition to the direct activation and modulation of nociceptive neuronal responses, EAA receptors may also indirectly modulate nociception via interactions with other nociceptive receptors. There is evidence suggesting that NMDA receptor mechanisms may modulate TRPV1 activity in the central nervous system. For example, studies have demonstrated that both the capsaicin-evoked release of spinal substance P (90) as well as the capsaicin-evoked antinociception at the periaqueductal grey level (91) may be dependent on the release of glutamate acting on NMDA receptors. Indeed, EAA receptor mechanisms may modulate TRPV1 processes in peripheral tissues. The authors have recently shown that there are functional TRPV1 receptors in deep craniofacial tissues and that they appear to be modulated by peripheral EAA receptor mechanisms. The authors first documented that capsaicin injected into the rat TMJ or craniofacial muscles produces an inflammatory response (92), evokes activity and peripheral sensitization in small-diameter, mechanosensitive fibres $(21,22)$, induces a dose-dependent reflex increase in jaw muscle EMG activity (74) and evokes central sensitization in brainstem nociceptive neurons $(86,93)$. The authors have also recently demonstrated that both trigeminal nociceptive afferent $(21,22)$ and brainstem $(87,94)$ nociceptive neuronal responses to capsaicin injected into the TMJ are significantly increased following glutamate injection into the TMJ or craniofacial muscles. These findings suggests that glutamate may sensitize primary afferent fibres and brainstem nociceptive neurons with deep craniofacial tissue receptive fields in rats and produce larger (eg, increased response magnitude and peak frequency), more immediate (eg, decreased response latency) and prolonged (increased response duration) nociceptive responses to subsequent noxious stimulation (eg, with capsaicin) of the TMJ. Peripheral NMDA receptors, in particular, may play a role in mediating capsaicin-evoked increases in jaw muscle EMG activity because preinjection of either the noncompetitive NMDA receptor antagonist MK-801 (95) or the competitive NMDA receptor antagonist 2-amino-5-phosphonovalerate acid (96) into the TMJ attenuates jaw muscle EMG activity evoked by capsaicin.

One possible mechanism whereby capsaicin or lowered $\mathrm{pH}$ (eg, elevated $\mathrm{H}^{+}$levels during inflammation) evokes nociceptive jaw muscle activity could involve autocrine and/or paracrine regulation of nociceptive excitability via ionotropic glutamate receptors (Figure 2). No studies to date have demonstrated the colocalization of peripheral NMDA and TRPV1 receptors on the same trigeminal primary afferent terminal, 


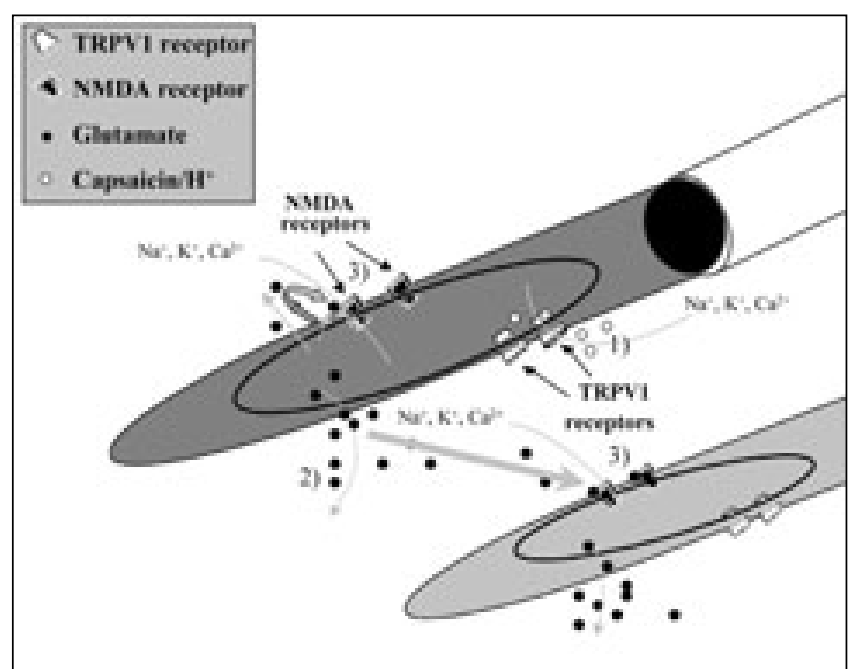

Figure 2) Proposed ionotropic glutamate receptor regulation of capsaicin or $\mathrm{H}^{+}$-induced nociceptive excitability. 1) Capsaicin or $\mathrm{H}^{+}$activates vanilloid type 1 (TRPV1) receptors in temporomandibular joint (TMJ) afferent fibres resulting in $\mathrm{Na}^{+}, \mathrm{K}^{+}$and $\mathrm{Ca}^{2+}$ influx and consequent membrane depolarization. 2) Capsaicin or $\mathrm{H}^{+}$-induced membrane depolarization results in neurogenic release of glutamate. 3) Released glutamate may act in an autocrine fashion to further depolarize the same TMJ afferent fibre via $N$-methyl-D-aspartate (NMDA) receptors and result in enhanced glutamate release or act in a paracrine fashion to activate NMDA receptors of adjacent TMJ afferent fibres

but the authors' recent evidence that peripherally applied glutamate and capsaicin may activate the same TMJ or craniofacial muscle fibre $(21,22)$ suggests that both receptors may be found on a single trigeminal primary afferent fibre. Similar peripheral NMDA receptor mechanisms may also play an important role in the nociceptive responses evoked by mustard oil. Jaw muscle activity evoked by mustard oil injected into the TMJ (14) as well as nocifensive behaviour (97), edema formation (97) and $c$-fos expression in the trigeminal brainstem nuclei (98) evoked by mustard oil injected into the masseter muscle are also similarly attenuated by local TMJ or muscle MK-801 pretreatment.

\section{Sex differences in peripheral EAA receptor mechanisms}

The prevalence of chronic pain conditions involving deep craniofacial tissues such as TMD and fibromyalgia is greater in women than men $(1,4,99-102)$, which suggests that sex-related factors may play a role in the pathogenesis of these conditions. Nevertheless, the mechanisms underlying these sex-related differences in the prevalence of craniofacial pain remain obscure and may involve a variety of factors, including physiological and psychosocial factors.

The authors' own data suggest that these sex differences may, in part, have a peripheral basis. Application of glutamate to the TMJ or masseter muscle evokes TMJ and muscle afferent and jaw muscle reflex EMG activity of greater magnitude in female than male rats $(16,17,19,23)$. Also noteworthy is that there is a sex difference in rats with respect to the peripheral application of opioids, where morphine co-application to the TMJ blocks glutamate-evoked jaw muscle activity in a dose-dependent and naloxone-reversible manner in male rats, whereas female rats show no such sensitivity (103). In contrast to these glutamate-evoked effects, there is no sex-related difference in the muscle afferent activity evoked by injection of hypertonic saline into the masseter muscle (23). These results raise the possibility that there may be distinct sex-related differences in some of the mechanisms involved in the processing of sensory inputs (such as glutamate) from deep craniofacial tissues and that these differences may contribute to the greater prevalence of many chronic muscle pain conditions in women.

The glutamate-related effect appears to be mediated, in part, by estrogen, because female gonadectomy eliminates these sexrelated differences, while estrogen replacement therapy restores them. In other animal studies, there is evidence for both peripheral and central neural sites of action for estrogen modulation of somatic sensation and nociceptive behaviour. Estrogen receptors are found in muscle $(104,105)$, TMJ $(106,107)$, dorsal root (108) and nodose ganglion neurons (109), indicating that deep tissues as well as peripheral ganglia are potential targets for sex steroids to modulate sensory and autonomic functions. Moreover, the trigeminal subnucleus caudalis region, the initial brainstem site of integration for nociceptive signals from the TMJ, may be another important target for sex hormone modulation because the superficial laminae near the caudal subnucleus caudalis region has been shown to express a high density of estrogen receptor-positive neurons $(110,111)$. Taken together, these results support the view that female rats may exhibit an enhanced neural responsiveness to injury of deep craniofacial tissues, which may be due in part to a sex-related increase in the excitability of trigeminal primary afferent fibres and central nociceptive neurons.

Proposed mechanisms of peripheral glutamate-mediated pain The above data suggest that changes in peripheral glutamate levels through cytosolic release from tissue damage, inflammation or neurogenic (vesicular) release from nociceptive activation may play an important role in modulating the sensitivity of deep craniofacial tissues through autocrine and/or paracrine regulation of ionotropic glutamate receptor mechanisms. Another possibility is that glutamate levels in deep tissues may be elevated by exogenous sources under certain conditions, for example after ingestion of food containing large quantities of monosodium glutamate. Ingestion of gram quantities of monosodium glutamate significantly elevates skeletal muscle content of glutamate (112) and sometimes results in facial pressure, burning and chest pain (113). Thus, in acute pain conditions, tissue injury, inflammation or noxious stimulation activates peripheral EAA receptors as well as other peripheral nociceptive receptors such as TRPV1. The activation of peripheral EAA receptors and consequent $\mathrm{Ca}^{2+}$ influx may enhance nociception via $\mathrm{Ca}^{2+}$-dependent phosphorylation of EAA and other receptors and/or further release of glutamate from neuronal terminals. The release of glutamate can then activate additional EAA receptors on the same neuronal terminal or adjacent surrounding peripheral terminals to amplify the release of glutamate in the peripheral tissues, sensitize other receptors such as TRPV1 and enhance nociceptive responses (Figure 2). It is then possible for chronic pain conditions to develop or be maintained via the continual autocrine and/or paracrine-regulated release of glutamate from peripheral neuronal terminals. In addition to the release of glutamate from affected neurons, non-neuronal cells such as macrophages (60), blood serum (61) or Schwann cells (62) that contain EAAs may also contribute to the increase in peripheral levels of glutamate following tissue damage, inflammation or nociceptive activation. This amplification of peripheral glutamate levels in deep craniofacial tissues may thus evoke peripheral sensitization and 
central sensitization as well as nociceptive jaw muscle reflex responses which may contribute to typical features of TMD (ie, neuromuscular changes reflected in limitations in jaw movements, plus pain spread and referral, allodynia, hyperalgesia and pain at rest).

\section{Human experimental masticatory pain model}

An important question is, do these various findings in rats have any relevance to nociceptive mechanisms in humans? The answer is yes. The demonstration of a novel nociceptive role for peripheral glutamate receptors in animal models led to investigations into whether injection of glutamate into the masseter muscle induces pain in human volunteers $(16,24,25)$. Glutamate injection into the masseter muscle has been found to cause significantly higher levels of peak pain, duration of pain, overall pain and pain spread than injection of isotonic saline in human volunteers (16). The glutamate-evoked pain spread, peak pain and overall muscle pain has also been found to be significantly greater in women than in men $(16,24,25)$. One possible mechanism to account for this difference between the sexes may be that women's masseter muscle afferent fibres have a greater sensitivity to glutamate, as demonstrated in the authors' animal model mentioned above. More recently, it has been demonstrated that the effect of glutamateevoked masseter muscle pain on the human jaw-stretch reflex also differs in men and women. Baseline jaw-stretch reflex responses were larger and glutamate injections into the masseter muscle were significantly more painful in women than in men, but glutamate significantly facilitated jaw-stretch reflex responses in men but not in women (24). Since one possible function of facilitated jaw-stretch reflex responses during jaw muscle pain may be to reduce jaw mobility and, thus, protect against further injury, the finding of a sex-related difference in the modulation of jaw-stretch reflex responses may prove to be important in clarifying why the prevalence of many chronic muscle pain conditions such as TMD and fibromyalgia is greater in women than in men.

Glutamate injection in humans also results in allodynia and pain spread, which is suggestive of peripheral sensitization and central sensitization, which the authors have shown can be induced by glutamate injections in rats (see above). It has been demonstrated that masseter muscle pressure pain thresholds were reduced (a sign of allodynia [25]), and that muscle pain also spread to involve the TMJ, the temporal regions and the teeth in many of the volunteers (16) following injection of glutamate into the masseter muscle. These findings suggest that activation of peripheral EAA receptors may excite nociceptors that contribute to pain responses in humans and is consistent with the association between the development of hyperalgesia and elevated tissue levels of glutamate elsewhere in the body (50). Furthermore, consistent with the authors' findings in rats, peripheral NMDA receptors may play a role in these effects of glutamate because it has been shown that ketamine (an NMDA antagonist) applied in combination with glutamate selectively decreases glutamate-evoked muscle pain in humans (23).

\section{CLINICAL RELEVANCE AND FUTURE DIRECTIONS}

Peripheral glutamate receptor mechanisms may have an important role in chronic pain conditions because peripheral glutamate levels $(43,49,50)$ as well as the number of peripheral glutamate receptors (51) are elevated during tissue inflammation. In particular, in craniofacial pain conditions such as TMD, an increase in peripheral levels of glutamate in craniofacial tissues may occur and result in the activation of peripheral glutamate receptors, modifying the excitability of trigeminal afferent fibres, thereby evoking pain. One possible mechanism that may contribute to the development of craniofacial pain involves autocrine and/or paracrine regulation of nociceptive neuronal excitability via injury or inflammationinduced release of glutamate. Recent studies in animals and humans do indeed suggest that the activation of peripheral glutamate receptors may contribute to craniofacial pain and to the female predominance in chronic pain disorders such as TMD and fibromyalgia. As detailed above, intramuscular or TMJ injection of glutamate in rats can evoke reflex increases in jaw muscle EMG activity (15), peripheral sensitization in deep craniofacial nociceptive primary afferent fibres $(16-18,21,22)$, and central sensitization in brainstem nociceptive neurons with deep craniofacial receptive fields (86). There is also a sex difference in rats with respect to the peripheral application of glutamate; TMJ and muscle afferent fibre and reflex jaw muscle responses are greater in female rats $(16,19)$. Similarly, intramuscular injection of glutamate can evoke pain and other features indicative of peripheral and central sensitization in humans, and there are sex differences in some of these effects $(16,24,25)$. The finding of a sex-related difference in pain responses to peripherally injected glutamate suggests that if selective peripheral EAA receptor antagonists can be developed, they could be used to determine whether peripheral EAA receptor activation is involved in the development or maintenance of craniofacial pain conditions in women.

Although a novel antinociceptive role for peripheral NMDA receptor antagonists in animal and human craniofacial pain models has been demonstrated $(15,23,95,96)$, there has been a paucity of reports on the effects of locally administered NMDA receptor antagonists in other human experimental craniofacial pain models, and data from the few existing human experimental pain models are not consistent. For example, Warncke et al (114) showed that local pretreatment with ketamine inhibited the development of mechanical hyperalgesia in a forearm burn injury model, and Pedersen et al (115) demonstrated that peripheral ketamine pretreatment reduced spontaneous pain during burn injury induction and increased the heat pain threshold using a similar burn injury model. In contrast to the results of the burn injury models and our finding that pre-injection of an NMDA receptor antagonist into the TMJ attenuates capsaicin-evoked jaw muscle EMG activity $(95,96)$, Gottrup et al $(116,117)$, using a capsaicin model, showed that ketamine had no effect on reducing spontaneous pain, evoked pain and areas of hyperalgesia induced by intradermal capsaicin injection in humans. Differences in pain models, dosages and timing of NMDA receptor antagonists and injury may explain the discrepancy in experimental results.

Animal and human studies suggest that the elevation of peripheral glutamate levels in deep craniofacial tissues may contribute to neuromuscular changes, pain spread and referral, allodynia, hyperalgesia, pain at rest and the female predominance manifested in many craniofacial pain conditions such as TMD and fibromyalgia. However, further studies are clearly required to achieve a better understanding of the role of 
peripheral glutamate receptors in the pathobiological mechanisms underlying these craniofacial pain conditions. The demonstration of a relationship between peripheral glutamate receptor mechanisms and craniofacial pain may lead to the development of novel diagnostic and therapeutic approaches for TMD and other craniofacial pain conditions of peripheral origin. Thus, peripheral glutamate receptors may be potential novel targets for the treatment of craniofacial pain conditions and may provide a rationale for nonopioid pain therapy. The formulation of specific peripheral ionotropic glutamate receptor antagonists that do not cross the blood-brain barrier may be of potential benefit by reducing peripheral nociceptive excitability and sensitization while avoiding any harmful central side effects associated with central glutamate receptor antagonism.

FUNDING: Support for this study was contributed by CIHR (MOP-43905) and NIH (DE15420). BJ Sessle and BE Cairns are recipients of Canada Research Chairs.

\section{REFERENCES}

1. Carlsson GE, LeResche L. Epidemiology of temporomandibular disorders. In: Sessle BJ, Bryant PS, Dionne RA, eds. Progress in Pain Research and Management, Vol 4. Temporomandibular Disorders and Related Pain Conditions. Seattle: IASP Press, 1995:211-26.

2. Wolfe F, Ross K, Anderson J, Russell IJ. Aspects of fibromyalgia in the general population: Sex, pain threshold, and fibromyalgia symptoms. J Rheumatology 1995;22:151-6.

3. LeResche L. Epidemiology of orofacial pain. In: Lund JP, Lavigne G, Dubner R, Sessle BJ, eds. Orofacial Pain: From Basic Science to Clinical Management. Carol Stream: Quintessence Publishing Co, 2001:15-25.

4. Maixner W, Fillingim R, Booker D, Sigurdsson A. Sensitivity of patients with painful temporomandibular disorders to experimentally evoked pain. Pain 1995;63:341-51.

5. Maixner W, Fillingim R, Sigurdsson A, Kincaid S, Silva S. Sensitivity of patients with temporomandibular disorders to experimentally evoked pain: Evidence for altered temporal summation of pain. Pain 1998;76:71-81

6. Stohler CS. Clinical perspectives on masticatory and related muscle disorders. In: Sessle BJ, Bryant PS, Dionne RA, eds. Progress in Pain Research and Management, Vol 4. Temporomandibular disorders and related pain conditions. Seattle: IASP Press, 1995:3-29.

7. Stohler CS. Muscle-related temporomandibular disorders. J Orofac Pain 1999;13:273-84.

8. Clauw DJ, Crofford LJ. Chronic widespread pain and fibromyalgia: What we know, and what we need to know. Best Pract Res Clin Rheumatol 2003;17:685-701.

9. Henriksson KG. Fibromyalgia - from syndrome to disease. Overview of pathogenetic mechanisms. J Rehabil Med 2003;41(Suppl):89-94.

10. Mense S, Simons DG, Russell IJ. Muscle Pain: Understanding Its Nature, Diagnosis and Treatment, 1st edn. Baltimore: Lippincott Williams \& Wilkins, 2000.

11. Schaible HG, Ebersberger A, Von Banchet GS. Mechanisms of pain in arthritis. Ann N Y Acad Sci 2002;966:343-54.

12. Zarb GA, Carlsson GE, Sessle BJ, Mohl ND. Temporomandibular Joint and Masticary Muscle Disorders, 2nd edn. Copenhagen: Blackwell Munksgaard, 1994.

13. Singer E, Dionne R. A controlled evaluation of ibuprofen and diazepam for chronic orofacial muscle pain. J Orofac Pain 1997;11:139-46.

14. Yu XM, Sessle BJ, Haas DA, Izzo A, Vernon H, Hu JW. Involvement of NMDA receptor mechanisms in jaw electromyographic activity and plasma extravasation induced by inflammatory irritant application to temporomandibular joint region of rats. Pain 1996;68:169-78.

15. Cairns BE, Sessle BJ, Hu JW. Evidence that excitatory amino acid receptors within the temporomandibular joint region are involved in the reflex activation of the jaw muscles. J Neurosci 1998;18:8056-64.

16. Cairns BE, Hu JW, Arendt-Nielsen L, Sessle BJ, Svensson P. Sex-related differences in human pain and rat afferent discharge evoked by injection of glutamate into the masseter muscle. J Neurophysiol 2001;86:782-91.
17. Cairns BE, Sessle BJ, Hu JW. Characteristics of glutamate-evoked temporomandibular joint afferent activity in the rat. J Neurophysiol 2001;85:2446-54.

18. Cairns BE, Gambarota G, Svensson P, Arendt-Nielson L, Berde CB. Glutamate-induced sensitization of rat masseter muscle fibers. Neurosci 2002;109:389-99.

19. Cairns BE, Sim Y, Bereiter DA, Sessle BJ, Hu JW. Influence of sex on reflex jaw muscle activity evoked from the rat temporomandibular joint. Brain Res 2002;957:338-44.

20. Fiorentino PM, Cairns BE, Hu JW. Development of inflammation after application of mustard oil or glutamate to the rat temporomandibular joint. Arch Oral Biol 1999:44:27-32.

21. Lam DK, Sessle BJ, Hu JW. Glutamate and capsaicin-evoked activity in deep craniofacial trigeminal nociceptive afferents. The IADR/AADR/CADR 82nd General Session. Honolulu, March 10-13, 2004. (Abst No 3817) <http://iadr.confex.com/iadr/ 2004Hawaii/techprogram/abstract_40876.htm > (Version current at March 29, 2005)

22. Lam DK, Sessle BJ, Hu JW. Glutamate and capsaicin-induced activation and peripheral sensitisation in deep craniofacial trigeminal nociceptive primary afferents. Neuroscience 2004. San Diego, October 23-27, 2004. (Abst No 294.6)

23. Cairns BE, Svensson P, Wang K, et al. Activation of peripheral NMDA receptors contributes to human pain and rat afferent discharges evoked by injection of glutamate into the masseter muscle. J Neurophysiol 2003;90:2098-105.

24. Cairns BE, Wang K, Hu JW, Sessle BJ, Arendt-Nielsen L, Svensson P. The effect of glutamate-evoked masseter muscle pain on the human jaw-stretch reflex differs in men and women. J Orofac Pain 2003; 17:317-25.

25. Svensson P, Cairns BE, Wang K, et al. Glutamate-evoked pain and mechanical allodynia in the human masseter muscle. Pain 2003;101:221-7.

26. Sato K, Kiyama H, Park HT, Tohyama M. AMPA, KA and NMDA receptors are expressed in the rat DRG neurones. Neuroreport 1993;4:1263-5.

27. Sahara Y, Noro N, Iida Y, Soma K, Nakamura Y. Glutamate receptor subunits GluR5 and KA-2 are co-expressed in rat trigeminal ganglion neurons. J Neurosci 1997;17:6611-25.

28. Carlton SM, Hargett GL, Coggeshall RE. Localization and activation of glutamate receptors in unmyelinated axons of rat glabrous skin. Neurosci Lett 1995;197:25-8.

29. Coggeshall RE, Carlton SM. Ultrastructural analysis of NMDA, AMPA, and kainate receptors on unmyelinated and myelinated axons in the periphery. J Comp Neurol 1998;391:78-86.

30. Battaglia G, Rustioni A. Coexistence of glutamate and substance P in dorsal root ganglion neurons of the rat and monkey. J Comp Neurol 1988;277:302-12.

31. Kai-Kai MA. Cytochemistry of the trigeminal and dorsal root ganglia and spinal cord of the rat. Comp Biochem Physiol A 1989;93:183-93.

32. Clements JR, Magnusson KR, Hautman J, Beitz AJ. Rat tooth pulp projections to spinal trigeminal subnucleus caudalis are glutamate-like immunoreactive. J Comp Neurol 1991;309:281-8.

33. Clements JR, Beitz AJ. An electron microscopic description of glutamatelike immunoreactive axon terminals in the rat principal sensory and spinal trigeminal nuclei. J Comp Neurol 1991;309:271-80.

34. Kai-Kai MA, Howe R. Glutamate-immunoreactivity in the trigeminal and dorsal root ganglia, and intraspinal neurons and fibres in the dorsal horn of the rat. Histochem J 1991;23:171-9.

35. Azerad J, Boucher Y, Pollin B. [Demonstration of glutamate in primary sensory trigeminal neurons innervating dental pulp in rats] C R Acad Sci III 1992;314:469-75.

36. Keast JR, Stephensen TM. Glutamate and aspartate immunoreactivity in dorsal root ganglion cells supplying visceral and somatic targets and evidence for peripheral axonal transport. J Comp Neurol 2000;424:577-87.

37. Westlund KN, McNeill DL, Coggeshall RE. Glutamate immunoreactivity in rat dorsal roots. Neurosci Lett 1989;96:13-7.

38. Westlund KN, Sun YC, Sluka KA, Dougherty PM, Sorkin LS, Willis WD. Neural changes in acute arthritis in monkeys. II. Increased glutamate immunoreactivity in the medial articular nerve. Brain Res Rev 1992;17:15-27.

39. Wanaka A, Shiotani Y, Kiyama H, et al. Glutamate-like immunoreactive structures in primary sensory neurons in the rat detected by a specific antiserum against glutamate. Exp Brain Res 1987;65:691-4. 
40. Skilling SR, Smullin DH, Larson AA. Extracellular amino acid concentrations in the dorsal spinal cord of freely moving rats following veratridine and nociceptive stimulation. J Neurochem 1988;51:127-32.

41. Boucher Y, Pollin B, Azerad J. Microinfusions of excitatory amino acid antagonists into the trigeminal sensory complex antagonize the jaw opening reflex in freely moving rats. Brain Res 1993;614:155-63.

42. Bereiter DA, Benetti AP. Excitatory amino release within spinal trigeminal nucleus after mustard oil injection into the temporomandibular joint region of the rat. Pain 1996;67:451-9.

43. Omote K, Kawamata T, Kawamata M, Namiki A. Formalin-induced release of excitatory amino acids in the skin of the rat hindpaw. Brain Res 1998;787:161-4.

44. deGroot J, Zhou S, Carlton SM. Peripheral glutamate release in the hindpaw following low and high intensity sciatic stimulation. Neuroreport 2000;11:497-502.

45. Carlton SM. Peripheral excitatory amino acids. Curr Opin Pharmacol 2001;1:52-6.

46. Puil E, Spigelman I. Electrophysiological responses of trigeminal root ganglion neurons in vitro. Neuroscience 1988;24:635-46.

47. Pelkey KA, Marshall KC. Actions of excitatory amino acids on mesencephalic trigeminal neurons. Can J Physiol Pharmacol 1998;76:900-8

48. Jackson DL, Hargreaves KM. Activation of excitatory amino acid receptors in bovine dental pulp evokes the release of iCGRP. J Dent Res 1999;78:54-60.

49. Lawand NB, McNearney T, Westlund KN. Amino acid release into the knee joint: Key role in nociception and inflammation. Pain 2000;86:69-74.

50. McNearney T, Speegle D, Lawand N, Lisse J, Westlund KN. Excitatory amino acid profiles of synovial fluid from patients with arthritis. J Rheumatol 2000;27:739-45

51. Carlton SM, Coggeshall RE. Inflammation-induced changes in peripheral glutamate receptor populations. Brain Res 1999;820:63-70.

52. Zhou S, Bonasera L, Carlton SM. Peripheral administration of NMDA, AMPA or KA results in pain behaviors in rats. Neuroreport 1996;7:895-900.

53. Lawand NB, Willis WD, Westlund KN. Excitatory amino acid receptor involvement in peripheral nociceptive transmission in rats. Eur J Pharmacol 1997;324:169-77.

54. Leem JW, Hwang JH, Hwang SJ, Park H, Kim MK, Choi Y. The role of peripheral $\mathrm{N}$-methyl-D-aspartate receptors in Freund's complete adjuvant induced mechanical hyperalgesia in rats. Neurosci Lett 2001;297:155-8.

55. Carlton SM, Zhou S, Coggeshall RE. Evidence for the interaction of glutamate and NK1 receptors in the periphery. Brain Res 1998; 790:160-9.

56. Davidson EM, Coggeshall RE, Carlton SM. Peripheral NMDA and non-NMDA glutamate receptors contribute to nociceptive behaviors in the rat formalin test. Neuroreport 1997;8:941-6.

57. Jackson DL, Graff CB, Richardson JD, Hargreaves KM. Glutamate participates in the peripheral modulation of thermal hyperalgesia in rats. Eur J Pharmacol 1995;284:321-5.

58. Davidson EM, Carlton SM. Intraplantar injection of dextrorphan, ketamine or memantine attenuates formalin-induced behaviors. Brain Res 1998;785:136-42.

59. Wang H, Liu RJ, Zhang R-X, Qiao J-T. Peripheral NMDA receptors contribute to the activation of nociceptors: A c-fos expression study in rats. Neurosci Lett 1997;221:101-4.

60. Piani D, Frei K, Do KQ, Cuenod M, Fontana A. Murine brain macrophages induce NMDA receptor mediated neurotoxicity in vitro by secreting glutamate. Neurosci Lett 1991;133:159-62.

61. McAdoo DJ, Hughes M, Xu G-Y, Robak G, DeCastro R. Microdialysis studies of the role of chemical agents in secondary damage upon spinal cord injury. J Neurotrauma 1997;14:507-15.

62. Parpura V, Lui F, Jeftinija K, Haydon PG, Jeftinija S. Neuroligand evoked calcium-dependent release of excitatory amino acids from Schwann Cells. J Neurosci 1995;15:5831-9.

63. Keele C, Armstrong D. Substances Producing Pain and Itch. Baltimore: Williams and Wilkins, 1964.

64. Fields HL. Pain. New York: McGraw-Hill, 1987.

65. Belmonte C, Cervero F. Neurobiology of Nociceptors. New York: Oxford University Press, 1996.
66. Cook SP, McCleskey EW. Cell damage excites nociceptors through release of cytosolic ATP. Pain 2002;95:41-7.

67. Waldmann R, Lazdunski M. H+-gated cation channels: Neurona acid sensors in the $\mathrm{NaC} / \mathrm{DEG}$ family of ion channels. Curr Opin Neurobiol 1998;8:418-24.

68. Caterina MJ, Schumacher MA, Tominaga M, Rosen TA, Levine JD, Julius D. The capsaicin receptor: A heat-activated ion channel in the pain pathway. Nature 1997;389:816-24.

69. Tominaga M, Caterina MJ, Malmberg AB, et al. The cloned capsaicin receptor integrates multiple pain-modulating stimuli. Neuron 1998:21:531-43

70. Benham CD, Gunthorpe MJ, Davis JB. TRPV channels as temperature sensors. Cell Calcium 2003;33:479-87.

71. Jordt SE, McKemy DD, Julius D. Lessons from peppers and peppermint: The molecular logic of thermosensation. Curr Opin Neurobiol 2003;13:487-92.

72. Huettner JE. Glutamate receptor channels in rat DRG neurons: Activation by kainate and quisqualate and blockade of desensitization by Con A. Neuron 1990;5:255-66.

73. Du J, Koltzenburg M, Carlton SM. Glutamate-induced excitation and sensitization of nociceptors in rat glabrous skin. Pain 2000;89:187-98.

74. Tang ML, Haas DA, Hu JW. Capsaicin-induced joint inflammation is not blocked by local anesthesia. Anesth Prog 2004;51:2-9.

75. Tsai CM, Chiang CY, Yu XM, Sessle BJ. Involvement of trigeminal subnucleus caudalis (medullary dorsal horn) in craniofacial nociceptive reflex activity. Pain 1999;81:115-28.

76. Cairns BE, Sessle BJ, Hu JW. Temporomandibular-evoked jaw muscle reflex: Role of brain stem NMDA and non-NMDA receptors. Neuroreport 2001;12:1875-8.

77. Hu JW, Tsai C-M, Bakke M, et al. Deep craniofacial pain: Involvement of trigeminal subnucleus caudalis and its modulation. In: Jensen TS, Turner JA, Wiesenfeld-Hallin, eds. Progress in Pain Research and Management. Seattle: IASP, 1997:497-506.

78. Sessle BJ. The neural basis of temporomandibular joint and masticatory muscle pain. J Orofac Pain 1999;13:238-45.

79. Sessle BJ. Acute and chronic craniofacial pain: Brainstem mechanisms of nociceptive transmission and neuroplasticity, and their clinical correlates. Crit Rev Oral Biol Med 2000;11:57-91.

80. Karim F, Bhave G, Gereau RW. Metabotropic glutamate receptors on peripheral sensory neuron terminals as targets for the development of novel analgesics. Mol Psychiatry 2001;6:615-7.

81. Neugebauer V. Peripheral metabotropic glutamate receptors: Fight the pain where it hurts. Trends Neurosci 2001;24:550-2.

82. Neugebauer V. Metabotropic glutamate receptors - important modulators of nociception and pain behavior. Pain 2002;98:1-8

83. Varney MA, Gereau RW. Metabotropic glutamate receptor involvement in models of acute and persistent pain: Prospects for the development of novel analgesics. Curr Drug Target CNS Neurol Disord 2002;1:283-96.

84. Gambarota G, Philippens M, Cairns BE, Dong XD, Renema WKJ, Heerschap A. MRS assessment of glutamate clearance in a novel masticatory muscle pain model. NMR Biomed 2005. (In press)

85. Riveros N, Fiedler J, Lagos N, Munoz C, Orrego F. Glutamate in rat brain cortex synaptic vesicles: Influence of the vesicle isolation procedure. Brain Res 1986;386:405-8

86. Lam DK, Teramoto K, Sessle BJ, Hu JW. Trigeminal nociceptive neuronal central sensitization induced by glutamate and capsaicin application to temporomandibular joint (TMJ) in male and female rats. Neuroscience 2003. New Orleans, November 8-12, 2003. (Abst No 175.2)

87. Teramoto K, Lam DK, Sessle BJ, Hu JW. Responses of trigeminal (V) nociceptive neurones to glutamate (GLU) and capsaicin (CAP) application to temporomandibular joint (TMJ) in male and female rats. Neuroscience 2003. New Orleans, November 8-12, 2003. (Abst No 175.1)

88. Hu JW, Sessle BJ, Raboisson P, Dallel R, Woda A. Stimulation of craniofacial muscle afferents induces prolonged facilitatory effects in trigeminal nociceptive brain-stem neurones. Pain 1992;48:53-60

89. Yu XM, Sessle BJ, Hu JW. Differential effects of cutaneous and deep application of inflammatory irritant on mechanoreceptive field properties of trigeminal brain stem nociceptive neurons. J Neurophysiol 1993;70:1704-7.

90. Afrah AW, Stiller CO, Olgart L, Brodin E, Gustafsson H. Involvement of spinal $\mathrm{N}$-methyl-D-aspartate receptors in capsaicin- 
induced in vivo release of substance $\mathrm{P}$ in the rat dorsal horn. Neurosci Lett 2001;316:83-6.

91. Palazzo E, de Novellis V, Marabese I, et al. Interaction between vanilloid and glutamate receptors in the central modulation of nociception. Eur J Pharmacol 2002;439:69-75.

92. Fiorentino PM, Cairns BE, Hu JW. Capsaicin-induced inflammation within temporomandibular joint involves VR-1 receptor mechanisms. J Dent Res 2000;79:321. (Abst)

93. Lam DK, Sessle BJ, Hu JW. Surgical incision can alter capsaicin (CAP)-induced central sensitization in rat brainstem nociceptive neurons. Neuroscience 2002. Orlando, November 2-7, 2002. (Abst No 157.7)

94. Lam DK, Sessle BJ, Hu JW. Trigeminal nociceptive neuronal activity modulated by glutamate and capsaicin application to rat TMJ. The 81st General Session of the International Association for Dental Research. Goteborg, Sweden, June 25-28, 2003. (Abst No 1178) $<$ http://iadr.confex.com/iadr/2003Goteborg/techprogram/ abstract_27362.htm> (Version current at March 30, 2005).

95. Lam DK, Sessle BJ, Cairns BE, Hu JW. NMDA Receptor antagonist application to rat TMJ attenuates capsaicin-evoked jaw muscle activity. 32nd Annual Meeting and Exhibition of the AADR. San Antonio, March 12-15, 2003. (Abst No 1112) $<$ http://iadr.confex.com/iadr/2003SanAnton/techprogram/ abstract 26106.htm $>$ (Version current at March 30, 2005).

96. Hu JW, Lam DK, Cairns BE, Sessle BJ. Peripheral NMDA Receptor modulation of capsaicin-evoked jaw muscle activity. Neuroscience 2003. New Orleans, November 8-12, 2003. (Abst No 175.3)

97. Ro JY. Contribution of peripheral NMDA receptors in craniofacial muscle nociception and edema formation. Brain Res 2003;979:78-84.

98. Ro JY, Capra NF, Masri R. Contribution of peripheral N-methyl$\mathrm{D}$-aspartate receptors to $\mathrm{c}$-fos expression in the trigeminal spinal nucleus following acute masseteric inflammation. Neurosci 2004;123:213-9.

99. Bennett RM. Fibromyalgia: The commonest cause of widespread pain. Compr Ther 1995;21:269-75.

100. Carlson RC, Reid KI, Curran SL, et al. Psychological and physiological parameters of masticatory muscle pain. Pain 1998;76:297-307.

101. Dao TT, LeResche L. Gender differences in pain. J Orofac Pain 2000;14:169-84.

102. LeResche L, Saunders K, Von Korff MR, Barlow W, Dworkin SF. Use of exogenous hormones and risk of temporomandibular disorder pain. Pain 1997;69:153-60.

103. Cai BB, Cairns BE, Sessle BJ, Hu JW. Sex-related suppression of reflex jaw muscle activity by peripheral morphine but not GABA. Neuroreport 2001;12:3457-60.
104. Dahlberg E. Characterization of the cytosolic estrogen receptor in rat skeletal muscle. Biochim Biophys Acta 1982;717:65-75.

105. Meyer HH, Rapp M. Estrogen receptor in bovine skeletal muscle. J Anim Sci 1985;60:294-300.

106. Aufdemorte TB, Van Sickels JE, Dolwick MF, et al. Estrogen receptors in the temporomandibular joint of the baboon (Papio cynocephalus): An autoradiographic study. Oral Surg Oral Med Oral Pathol 1986;61:307-14

107. Milam SB, Aufdemorte TB, Sheridan PJ, Triplett RG, Van Sickels JE, Holt GR. Sexual dimorphism in the distribution of estrogen receptors in the temporomandibular joint complex of the baboon. Oral Surg Oral Med Oral Pathol 1987;64:527-32.

108. Sohrabji F, Miranda RC, Toran-Allerand CD. Estrogen differentially regulates estrogen and nerve growth factor receptor mRMAs in adut sensory neurons. J Neurosci 1994;14:459-71.

109. Papka RE, Srinivasan B, Miller KE, Hayashi S. Localization of estrogen receptor protein and estrogen receptor messenger RNA in peripheral autonomic and sensory neurons. Neuroscience 1997;79:1153-63.

110. Amandusson A, Hermanson O, Blomqvist A. Colocalization of oestrogen receptor immunoreactivity and preproenkephalin mRNA expression to neurons in the superficial laminae of the spinal and medullary dorsal horn of rats. Eur J Neurosci 1996;8:2440-5.

111. Okamoto K, Hirata H, Takeshita S, Bereiter DA. Response properties of TMJ units in superficial laminae at the spinomedullary junction of female rats vary over the estrous cycle. J Neurophysiol 2003;89:1467-77.

112. Graham TE, Sgro V, Friars D, Gibala MJ. Glutamate ingestion: The plasma and muscle free amino acid pools of resting humans. Am J Physiol Endocrinol Metab 2000;278:E83-9.

113. Schaumburg HH, Byck R, Gerstl R, Mashman JH. Monosodium L-glutamate: Its pharmacology and role in the Chinese restaurant syndrome. Science 1969;163:826-8.

114. Warncke T, Jørum E, Stubhaug A. Local treatment with N-methylD-aspartate receptor antagonist ketamine inhibits development of secondary hyperalgesia in man by a peripheral action. Neurosci Lett 1997;227:1-4.

115. Pedersen JL, Galle TS, Kehlet H. Peripheral analgesic effect of ketamine in acute inflammatory pain. Anesthesiology 1998;89:58-66.

116. Gottrup H, Bach FW, Arendt-Nielsen L, Jensen TS. Peripheral lidocaine but not ketamine inhibits capsaicin-induced hyperalgesia in humans. Br J Anaesth 2000;85:520-8.

117. Gottrup H, Bach FW, Jensen TS. Differential effects of peripheral ketamine and lidocaine on skin flux and hyperalgesia induced by intradermal capsaicin in humans. Clin Physiol Funct Imaging 2004;24:103-8 


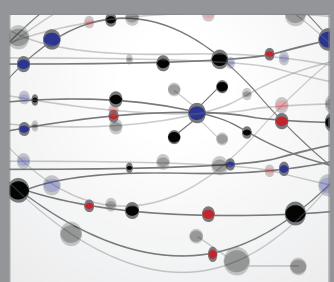

The Scientific World Journal
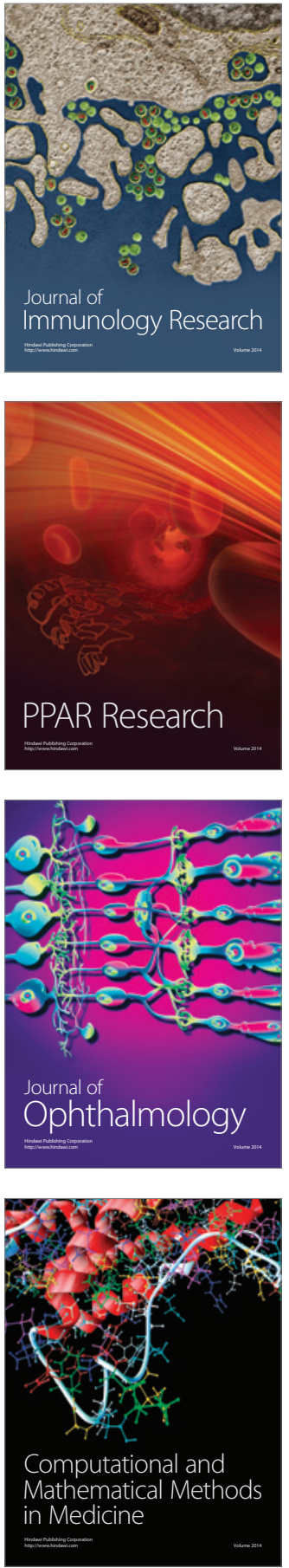

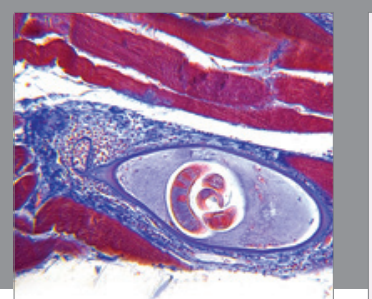

Gastroenterology Research and Practice

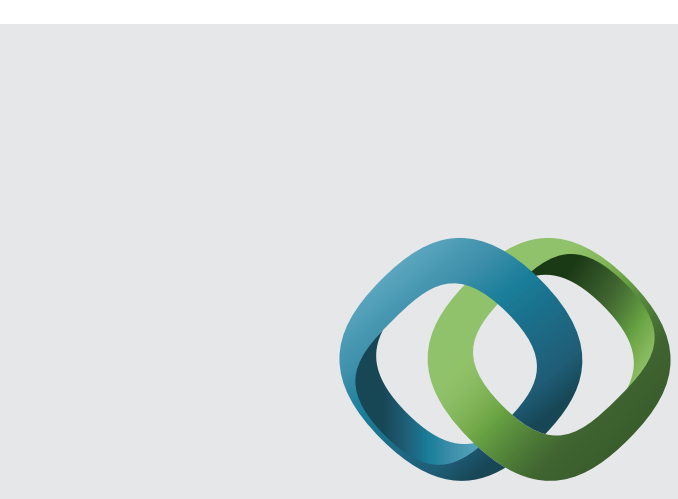

\section{Hindawi}

Submit your manuscripts at

http://www.hindawi.com
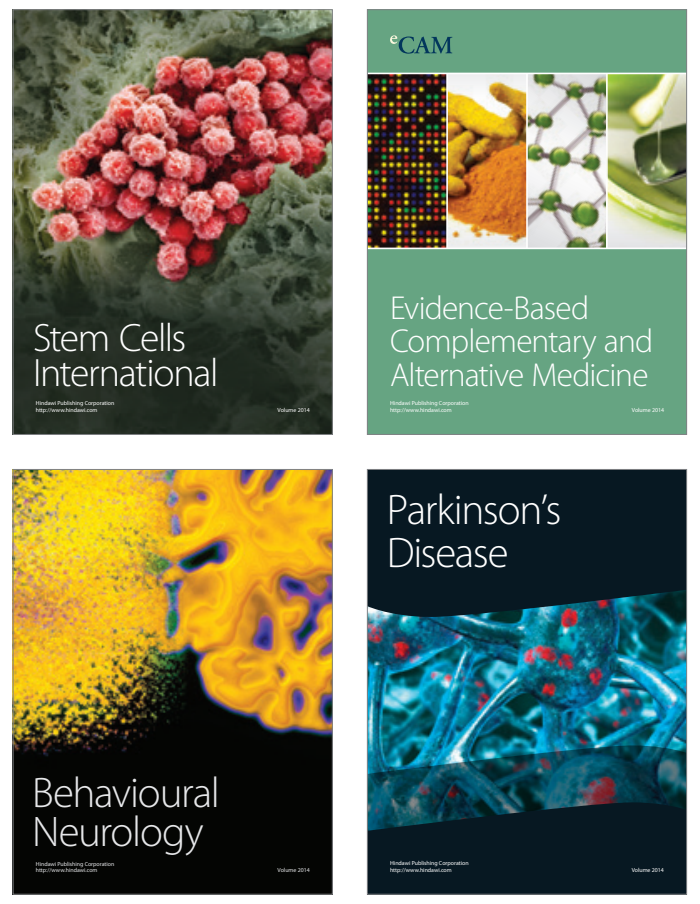
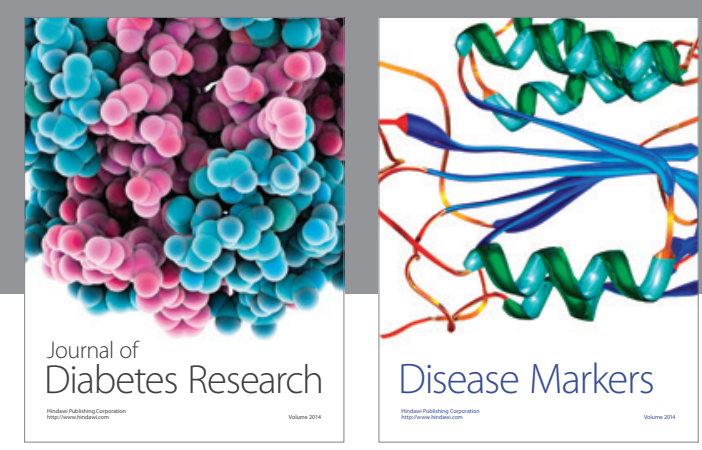

Disease Markers
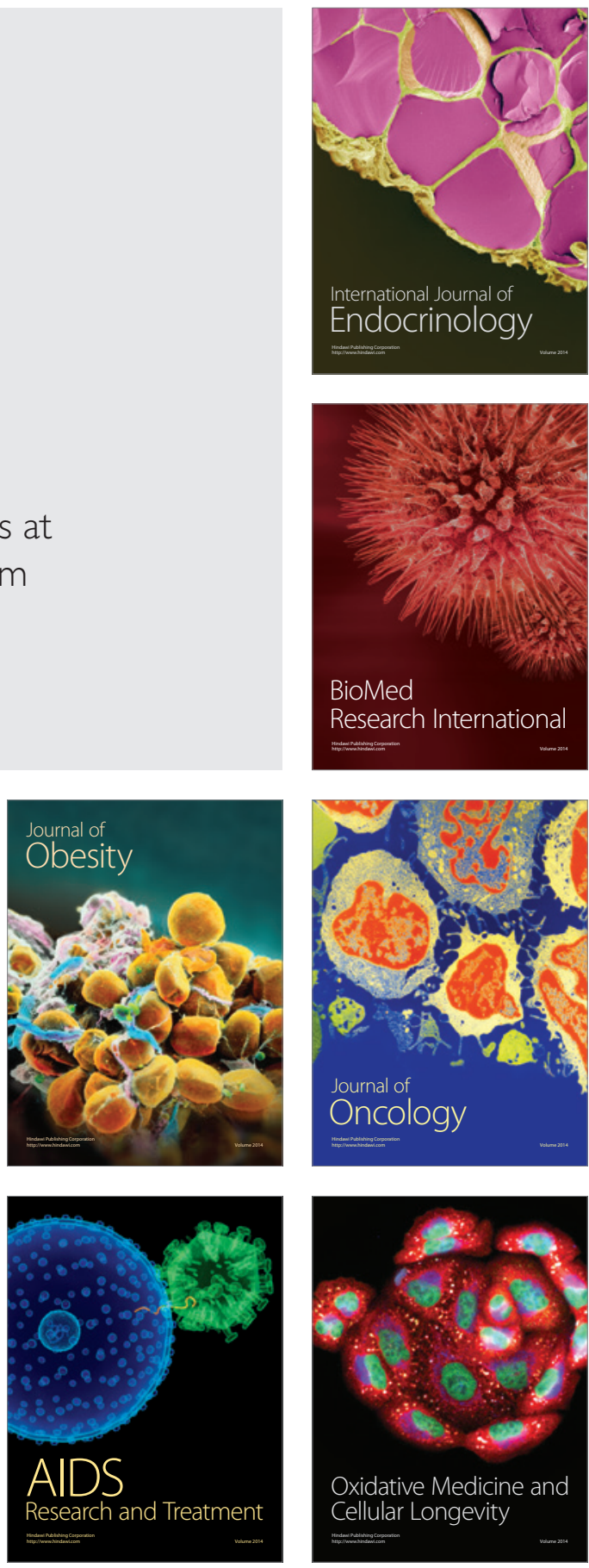